IWONA SAGAN D

Uniwersytet Gdański

\title{
BOHDANA JALOWIECKIEGO ROLA I ZNACZENIE W ROZWOJU POLSKICH BADAŃ MIEJSKICH
}

Lapidarnie ujmując rolę i znaczenie dorobku Bohdana Jałowieckiego w rozwoju polskich badań miejskich, należy stwierdzić, że bez jego wkładu studia miejskie w Polsce byłyby innymi studiami.

Studia miejskie to obecnie jeden z najsilniejszych kierunków badań społeczno-gospodarczo-przestrzennych rozwijanych w nauce światowej. Polskie badania miast w pełni wpisują się w ten nurt. W ogromnym stopniu jest to zasługą Bohdana Jałowieckiego. Fakt, że polscy badacze uczestniczą w światowym dialogu naukowym wynika $\mathrm{z}$ otwartości i interdyscyplinarności tych badań w naszym kraju. Prace Bohdana Jałowieckiego w ogromnym stopniu przyczyniły się zarówno do ewolucji i rozwoju studiów miejskich, jak i do ich umiędzynarodowienia. Jego zasługa jest szerokie wprowadzenie do polskiej kultury badawczej między innym wielkiej tradycji francuskiej szkoły socjologii miasta zbudowanej na silnym fundamencie prac filozofów francuskich.

Ewolucję badań miejskich, która dokonywała się w ogromnej mierze za sprawą działalności naukowej Bohdana Jałowieckiego, postaram się zilustrować na przykładzie miejskich studiów geograficznych. Interdyscyplinarne ze swej natury studia miejskie były bowiem polem badawczym, na którym skrzyżowały się drogi mojego rozwoju naukowego jako początkującego geografa społecznego i naukowej aktywności Jałowieckiego, która inspirowała przenikliwością refleksji i nowatorstwem.

W polskiej tradycji geograficznej niemal do połowy lat 80 . XX wieku badania miejskie traktowane były jako wąska specjalizacja badawcza w ramach geografii

Prof. dr hab., Wydział Nauk Społecznych; e-mail: iwona.sagan@ug.edu.pl; https://orcid.org/0000-0001-6363-3831 
osadnictwa. Jeszcze na początku lat 80. Kazimierz Dziewoński [1982: 121] pisał, że geografia miast jest tylko częścią geografii osadnictwa i ludności i w żadnej mierze nie wyczerpuje jej szerokiego zakresu badawczego. Analizy rozwoju miast prowadzone były głównie z perspektywy miasta jako elementu sieci osadniczej [Dziewoński 1972, 1982, 1990; Golachowski 1971; Liszewski (red.) 1994; Liszewski $1997 \mathrm{i}$ in.]. W tym podejściu obecna była również szkoła francuska, ale nie wykraczała ona poza powszechnie wykorzystywany podręcznik Jacqueline Beaujeu-Garnier i Georges'a Chabota Zarys geografii miast z 1971, na którym przez lata edukowane były kolejne pokolenia studentów. Wprowadzenie przez B. Jałowieckiego do badań miejskich prac Henriego Lefebvre'a, przetłumaczenie na język polski przełomowej Kwestii miejskiej Manuela Castellsa [1982] zmieniły sposób uprawiania i rozumienia studiów miejskich w Polsce. Dotyczyło to nie tylko studiów prowadzonych w obszarze badań geograficznych. Nowa dynamika i nowe podejście do kwestii miejskiej sprawiły, że rozwój badań nad miastem jako złożonym konstruktem społeczno-przestrzennym z pozycji jedynie wąskiej specjalizacji w ramach szeroko definiowanych studiów osadniczych skupionych na analizach sieci osadniczych stał się dominującym kierunkiem badań. Co więcej, tak ujmowana problematyka miejska zaczęła być obecna w licznych nurtach badań społeczno-ekonomicznych, dotychczas niedostrzegających potrzeby wyróżniania środowiska miejskiego jako wymagającego szczególnej i odrębnej metodologii badawczej.

Sposób uprawiania studiów miejskich przez B. Jałowieckiego wpłynął na silną interdyscyplinaryzację tych badań. W zdominowanych przez badania fizjonomiczno-morfologiczne przestrzennych studiach miejskich Jałowiecki zaszczepił dorobek polskich socjologów miasta [Wallis 1971; Pióro (red.) 1982], wprowadzając nurt ekologii społecznej miast do geograficzno-przestrzennej tradycji badawczej, a tą drogą także do praktyk planistycznych. Znaczenie prac Jałowieckiego w powiązaniu miejskich badań prowadzonych w obszarze studiów społeczno-ekonomicznych i miejskich studiów socjologicznych jest fundamentalne. Sprawił on, że socjologia miasta została silnie uprzestrzennio$n a$, natomiast geografia miasta uspołeczniona. Funkcjonując na styku różnych dyscyplin, Jałowiecki był w stanie dobrze oddać ich specyfikę, podkreślając, że perspektyw analizy miasta jest wiele i dopiero ich suma przybliża nas do poznania rzeczywistości społeczno-przestrzennej, która jest fenomen miasta [por. Jałowiecki, Szczepański 2002]. To Jałowiecki [2010] jako pierwszy wprowadził za Lefebvre'em [2009] do polskiej tradycji badawczej pojęcie społecznego wytwarzania przestrzeni, które budziło najpierw wiele kontrowersji w naukowym establishmencie, a dziś jest określeniem kanonicznym. 
Łączenie w jednolity nurt badawczy rozproszonych w ramach różnych dyscyplin studiów nad miastem było bardzo wcześnie podjętą przez B. Jałowieckiego aktywnością naukową. Już w 1971 roku ukazała się zredagowana przez niego publikacja Miasto jako przedmiot badań naukowych, z wprowadzającym rozdziałem autorstwa redaktora pt. Wspólne płaszczyzny badań różnych dyscyplin nad miastem. Tom ten oddaje ówczesnego ducha czasu, czyli jest utrzymany w paradygmacie scjentystycznym, z dominacją zastosowań ogólnej teorii systemów do badań miast i sieci osadniczych. Potwierdzeniem dominujących w tym czasie podejść formalnych w metodyce badawczej jest tekst Ryszarda Domańskiego otwierający zbiór artykułów.

Dziesięć lat po publikacji Miasta jako przedmiotu badań naukowych B. Jałowiecki wydał drugi tom pod tym samym tytułem, pisząc we wstępie do niego, że po okresie zafascynowania metodami ilościowymi i próbami kwantyfikowania wszystkiego nastapiła pewna refleksja krytyczna [1982: 9].

Na początku XXI wieku dokonał ponownej reasumpcji interdyscyplinarnego dorobku studiów miejskich, redagując tom pt. Miasto jako przedmiot badań naukowych w poczatkach XXI wieku [2008].

Idea redakcji interdyscyplinarnych tomów podsumowujących kolejne dekady rozwoju studiów miejskich opisanych z perspektywy różnych dyscyplin dowodzi świadomego kształtowania i rozwijania polskich badań miejskich jako spójnego nurtu badawczego. Kolekcja kolejnych tomów jest też cenną kroniką zmian w problematyce i metodologii prowadzenia studiów miejskich. Rola twórców tej miary, jakiej był Jałowiecki, w rozwoju dyscypliny jest nie do przecenienia.

Prace Bohdana Jałowieckiego ewoluowały w swej tematyce zgodnie z kierunkami zmian w światowych studiach miejskich. Jałowiecki, będąc stale w awangardzie badań studiów nad miastem, stopniowo przesuwał w swych pracach punkt zainteresowania ze struktur społecznych i przestrzennych na społeczne zachowania przestrzenne. Coraz liczniej w jego dorobku zaczęły pojawiać się studia nad teorią wyborów przestrzennych. Wiedza wyobrażeniowa, stany emocjonalne, jednym słowem: subiektywne doświadczanie przestrzeni, zaczęło zajmować za sprawą jego prac poczesne miejsce w polskich badaniach miast. To Jałowiecki inicjował, wspierał i współuczestniczył w badaniach percepcji i waloryzacji przestrzeni miejskiej, we wdrażaniu koncepcji miejsca w pionierskich w Polsce pracach Hanny Libury [1990]. Prace te formowały podwaliny pod rozwój podejść humanistycznych. Stanowią one dziś fundament badawczy interpretacji humanistycznych, a w szerszym ujęciu - studiów behawioralnych w polskiej literaturze przedmiotu. 
Dynamicznie zmieniające się wraz z transformacją systemową oblicze polskich miast, nowe, dotąd nieobecne problemy wynikające z rozwoju neoliberalnej gospodarki i demokratyzacji struktur władzy rodziły nowe zjawiska społeczno-przestrzenne. Segregacja i polaryzacja przestrzeni miejskiej, osiedla grodzone to tematy badawcze, których podjęcia na gruncie studiów miejskich wymagała tworząca się nowa rzeczywistość miejska. Jałowiecki liderował badawczo tematom, które wzbogacały i poszerzały pole analityczne polskich studiów miejskich. W 2006 roku jako jeden z pierwszych zorganizował sympozjum poświęcone gettoizacji przestrzeni miast.

Analizy zachowań decyzyjnych, wyborów lokalizacyjnych w mieście nie są podejmowane w próżni, lecz w określonych warunkach społeczno-politycznych. Uwarunkowania zewnętrzne są równie istotne, jak sam mechanizm decyzyjny. Zależności te nieuchronnie wprowadzały Jałowieckiego w obszar badań polityki miejskiej. Z tych uwarunkowań i z obserwacji dynamiki procesów urbanizacyjnych wyrastały badania formujących się obszarów metropolitalnych. Publikacje Jałowieckiego dotyczące tej problematyki były jednymi z pierwszych i najbardziej kompleksowych opracowań przybliżających międzynarodowy dorobek polskim badaczom i interpretujących konceptualne uogólnienia w odniesieniu do realiów młodej i kruchej demokracji w kraju [2002].

Niezmiernie bogaty i różnorodny dorobek badawczy, bezbłędne wyczuwanie konieczności zmian w prowadzonych kierunkach badań i dostrzeganie na horyzoncie nowych problemów, gdy inni ich jeszcze nie widzieli, dowodzi ogromnej wiedzy, intuicji i wrażliwości badawczej Jałowieckiego. Wydaje się jednak, że wielka praca i doświadczenie badawcze to nie wszystko. Osiagnnięcie tak imponujących efektów i odegranie tak znaczącej roli w polskich studiach miejskich było możliwe dzięki prawdziwej miłości Bohdana Jałowieckiego do miasta, której dał wyraz w swej książce Okruchy miast [2009]. Jak Autor pisze w otwierającej książkę dedykacji, obrazy miast, które utrwalił w słowie, są utkane z rzeczywistości, książek, anegdot, obrazów, filmów i piosenek, ze snów. Żeby wyjść poza rzemiosło nauki i stać się jej artysta, potrzebna jest miłość do swego dzieła. I chyba w tym kryje się tajemnica twórczej obecności Bohdana Jałowieckiego w polskich studiach miejskich, w polskiej nauce. 


\section{BIBLIOGRAFIA}

Beaujeu-Garnier Jacqueline, Georges Chabot. 1971. Zarys geografii miast. Warszawa: Polskie Wydawnictwo Ekonomiczne.

Castells Manuel. 1982. Kwestia miejska. Warszawa: PWN.

Dziewoński Kazimierz. 1972. „Kierunki badań osadnictwa w Polsce na tle badań w nauce światowej”. Studia nad Ekonomika Regionu 3: 43-56.

Dziewoński Kazimierz. 1982. Nowe kierunki badawcze w polskiej geografii miast. W: Miasto jako przedmiot badań naukowych - refleksje po 10 latach, B. Jałowiecki (red.), 121-139. Górnośląskie Studia Socjologiczne, tom XV. Katowice: Śląski Instytut Naukowy.

Dziewoński Kazimierz. 1990. „Geografia osadnictwa i ludności w Polsce 1945-1989. Mechanizmy rozwoju”. Prace Geograficzne IGiPZ PAN 154: 264-285.

Golachowski Stefan. 1971. Miasto jako przedmiot badań geografii. W: Miasto jako przedmiot badań naukowych, B. Jałowiecki (red.), 74-89. Górnośląskie Studia Socjologiczne, tom IX. Katowice: Śląski Instytut Naukowy.

Jałowiecki Bohdan. 1971. Miasto jako przedmiot badań naukowych. Górnośląskie Studia Socjologiczne, tom IX. Katowice: Śląski Instytut Naukowy.

Jałowiecki Bohdan. 1982. Miasto jako przedmiot badań naukowych - refleksje po 10 latach. Górnośląskie Studia Socjologiczne, tom. XV. Katowice: Śląski Instytut Naukowy.

Jałowiecki Bohdan. 2002. Zarządzanie rozwojem aglomeracji miejskich. Białystok: Wyższa Szkoła Finansów i Zarządzania w Białymstoku.

Jałowiecki Bohdan (red.). 2008. Miasto jako przedmiot badań naukowych $w$ poczatkach XXI wieku. Warszawa: Wydawnictwo Naukowe Scholar.

Jałowiecki Bohdan. 2009. Okruchy miast. Kraków-Rzeszów-Zamość: Konsorcjum Akademickie.

Jałowiecki Bohdan. 2010. Społeczne wytwarzanie przestrzeni. Warszawa: Wydawnictwo Naukowe Scholar.

Jałowiecki Bohdan, Marek S. Szczepański. 2002. Miasto i przestrzeń w perspektywie socjologicznej. Warszawa: Wydawnictwo Naukowe Scholar.

Lefebvre Henri. 2009 [1974]. The production of space. Oxford: Blackwell.

Libura Hanna. 1990. Percepcja przestrzeni miejskiej. Rozwój Regionalny, Rozwój Lokalny Samorząd Terytorialny, 31. Warszawa: Uniwersytet Warszawski.

Liszewski Stanisław (red.). 1994. Geografia osadnictwa i ludności w niepodległej Polsce. Lata 1918-1993, t. II: Kierunki badań naukowych. Łódź: PTG.

Liszewski Stanisław. 1997. Miasto w centrum zainteresowań geografa. W: Współczesne przemiany struktur przestrzennych dużych miast. IX Konwersatorium Wiedzy o Mieście, J. Kaczmarek (red.), 13-23. Łódź: UŁ, PTG, ŁTN.

Pióro Zygmunt (red.). 1982. Przestrzeń i społeczeństwo: z badań ekologii społecznej. Warszawa: Książka i Wiedza.

Wallis Aleksander. 1971. Socjologia i kształtowanie przestrzeni. Warszawa: Państwowy Instytut Wydawniczy. 